\title{
STUDYING THE INFLUENCE OF DIFFERENT COOLING TECHNIQUES ON PHOTOVOLTAIC-CELLS PERFORMANCE
}

\author{
Ahmed H. Ali", Khalid H. M. Abdalrahman, S. S. Wahid \\ Department of mechanical engineering, Faculty of Engineering, Minia University, 61519 Minia, Egypt \\ * Correspondence: ahmali777@ gmail.com; Tel: +201066059603; Fax: +20 86236674
}

\section{Article information}

Received: 12 May 2019

Revised: 9 July 2019

Accepted: 10 July 2019

\section{Key words}

Solar cell

Photovoltaic

Heat transfer

Water cooling

Fins

\begin{abstract}
The effect of temperature on the electrical parameters of photovoltaic cells is negative. The efficiency of photovoltaic cells can be enhanced by cooling which the temperature is considered as one of the main factors that affect negatively on the output power. This study was carried out to compare between three different cooling techniques and determine their effects on the output power. The first, cooling techniques is applied, the panel front surface cooled using the water spray on the surface. The second, the panel back surface cooled by extended fins. The third, the panel back surface cooled by extended fins with fans. As expected, the results of comparisons different methods using in cell cooling showed that, there is an increase in the efficiency of photovoltaic cells with the drop in cell temperature, which helps to increase the rate of photovoltaic cell performance and output power. In these experiments the output power increased $2.5 \%$. At the first technique using water spray method the temperature dropped 7 degrees. At the other two methods the temperature dropped 3 degrees less than the panel without cooling. The used pump and fans were power consuming. So, the most effective method was cooling using the fins.
\end{abstract}

\section{Introduction}

Solar energy considers one of the most important renewable energy sources. Photovoltaic-cells (PV) are the most widespread technology. PV devices convert sunlight into electricity [1]. The cumulative power produced form all major countries increased to $100 \mathrm{GW}$ during at 2012 [2]. PV cells performance depending on the operating temperature as the panels 'efficiency almost $15 \%$. The remaining absorbed energy converted into heat raises the PV panels' temperature which makes the thermal management is necessary. [3]. PV standard test conditions state that when the panels work under $25{ }^{\circ} \mathrm{C}$ the efficiency drops $0.5 \%$ for every degree increasing in temperature [1] So, many researches and experiments try to reduce PV cell temperature during operation. Cooling techniques can be divided into two techniques Passive cooling technique and active cooling technique. The most famous passive techniques are phase change material (PCM) heat sinks and water whose efficiency average is from $2 \%$ to $6 \%$ where air and radiative based passive cooling techniques are getting less attention due to their less efficiency. The average of increasing temperature for the liquid based immersion passive cooling is from $1.0 \%$ to $22 \%$, liquid based active cooling technique is from $10 \%$ to $15 \%$, air based cooling technique is from $3 \%$ to $5 \%$, radiative based cooling technique is from 0.5 $\%$ to $1.0 \%$. Liquid based passive cooling technique is the best at the output efficiency but it is hard from the technical point of view. The water based cooling technique considered the best choice for the practical terms (water spray or apply a layer of water in the front side) $[4,5]$. S. Nižetic, et al. used water spray cooling which decreased the temperature from $52{ }^{\circ} \mathrm{C}$ to 24 ${ }^{\circ} \mathrm{C}$ in average and increased the output power to $7.7 \%$ [6]. Also K.A. Moharram et al. designed spray system with nonpressurized water for cleaning and cooling the panels using a mathematical model determined the heating rate. At the experiment condition, the designed system operates every $5 \mathrm{~min}$ with cooling rate $2{ }^{\circ} \mathrm{C} / \mathrm{min}$ in order to decrease the panel temperature $10{ }^{\circ} \mathrm{C}$ [7]. Xiao Tang et al. [8] increased output power by $8.4 \%$ using water flow in novel micro heat pipe array [8]. Saurabh Mehrotra et al. [9] increased output power by 17.8 $\%$ using immersion PV cell at water at depth $1 \mathrm{~cm}$ [9]

\section{Methodology}

\subsection{Experimental setup:}

\subsubsection{Solar Panel Characteristics:}

Two poly crystalline solar panels used. Each panel has output power of 20 Watts and dimensions of $520 * 340 * 17 \mathrm{~mm}$, as shown in (Figure 1).

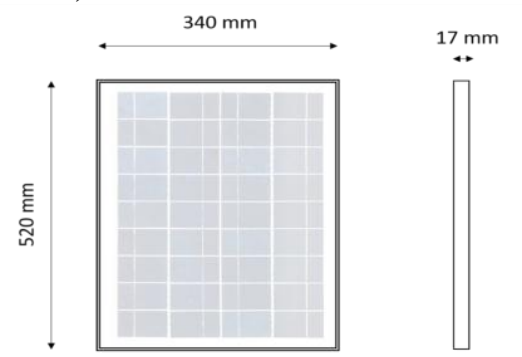

Figure 1: experiment setup: dimentions of the used solar panel 


\subsubsection{Fins Characteristics}

Four aluminum heat-sink each one has 19 thin fins with dimensions of $90 * 65 * 80 \mathrm{~mm}$, as shown in (Figure 2).

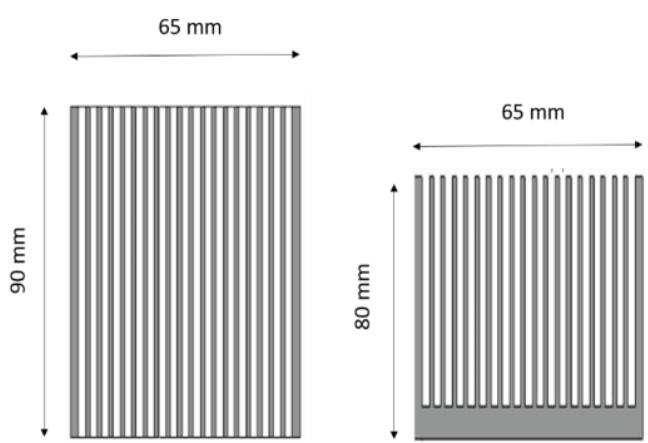

Figure 2:experiment setup: fins characteristics

\subsubsection{Fans Characteristics}

Four small plastic fans. Each fan has dimensions of 60*60mm, as shown in (Figure 3).

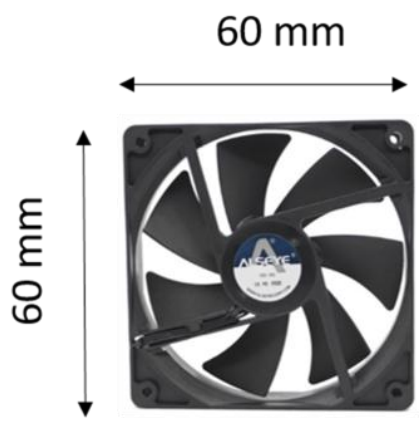

Figure 3:experiment setup: fan characteristics

\subsection{Experimental conditions}

The experiments were done in October 2017, between 1:00 and 3:00 PM. The weather was clear and sunny with ambient temperature of $37^{\circ} \mathrm{C}$ the angle of used panel is $25^{\circ}$.

\subsection{Experimental procedures}

Experiments for cooling the solar panels were developed to compare between three different techniques and its influence on the performance of the solar cells. The heat-reduction experiments were applied separately in the same operating conditions. In each experiment, the techniques applied on two identical panels, one of which is added to the cooling method and the other without cooling mode, to determine the effect of heat on the efficiency of the cell accurately.

\subsubsection{Water spray method}

In the first experiment, water cooling technique applied using low-power water pump connected to pipe line with holes above the panel. Every five minutes, the pump switched on for 30 seconds, to cool the panel front surface. The pump work 12 times/h, as shown in (Figure 4).

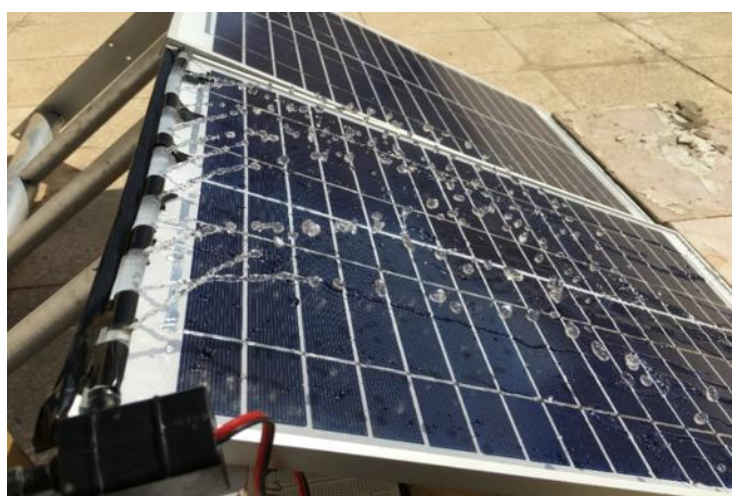

Figure 4:experiment 1. Water spray cooling technique using power pump connected to pipe line with holes at the panel's front side.

\subsubsection{Heat sink cooling technique}

In the second experiment, four heat-sinks with fins attached to the panel pack surface using Ceramic paste to make a good contact between fins and rear cell surface, as shown in (Figure 5).

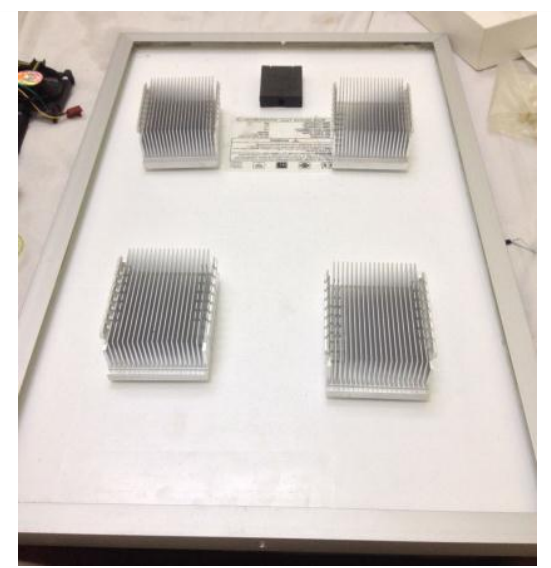

Figure 5:experiment2. passive cooling technique using four heat sinks with fins connected at the panel's back side.

\subsubsection{Cooling with fins and fans}

In the third experiment, four fans added to the fins to absorb more heat using forced convection. Each fan switched on for 30 seconds every five minutes. Fans work 12 times/h, as shown in (Figure 6).

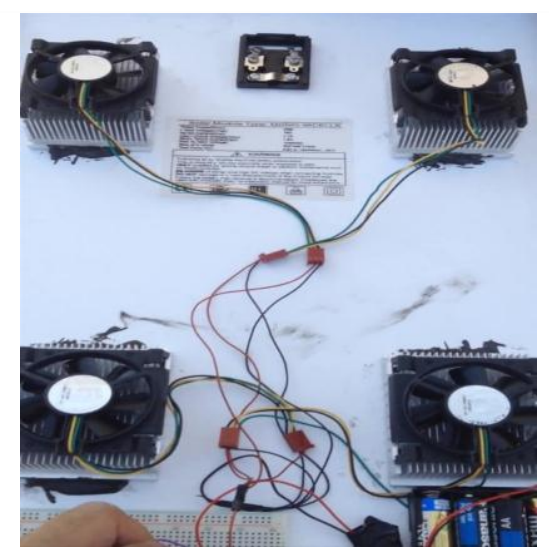

Figure 6: experiment3. Passive cooling technique using fins and fans connected at the panel's back side. 


\section{Results}

\subsection{Water sprays cooling technique results}

\section{Changing in temperature with time}

This experiment study the effect of water sprays cooling technique. Two similar panels were placed at angle of $25^{\circ}$. First panel was left without any cooling, while the other one was added by a small water pump to cool it with water flow. The pump was switched on every five minutes for 30 seconds to decrease the power consumed by pump. The pump works 12 times/ h. The temperature and power were measured several times at the peaks sun hours. This cooling method reduced the temperature of the panel about $7^{0} \mathrm{C}$ lower than the panel without cooling, as shown in (Figure7).

\section{Power changing with time}

Due to the effect of cooling temperature drop, the total power produced increased about 0.5 watt i.e. $2.5 \%$ of panel power, as shown in (Figure 8).

\section{Power consumed statistics}

Pump voltage: $9 \mathrm{~V}$

Pump current: 0.08 A

Pump power: 0.72 watts

Pump power/hours: $0.72 *(12 * 30) / 3600=0.072 \mathrm{watt} / \mathrm{h}$

Where, (12) represents is the numbers of pump switch on per hour, 30 represents time of switch off in seconds.

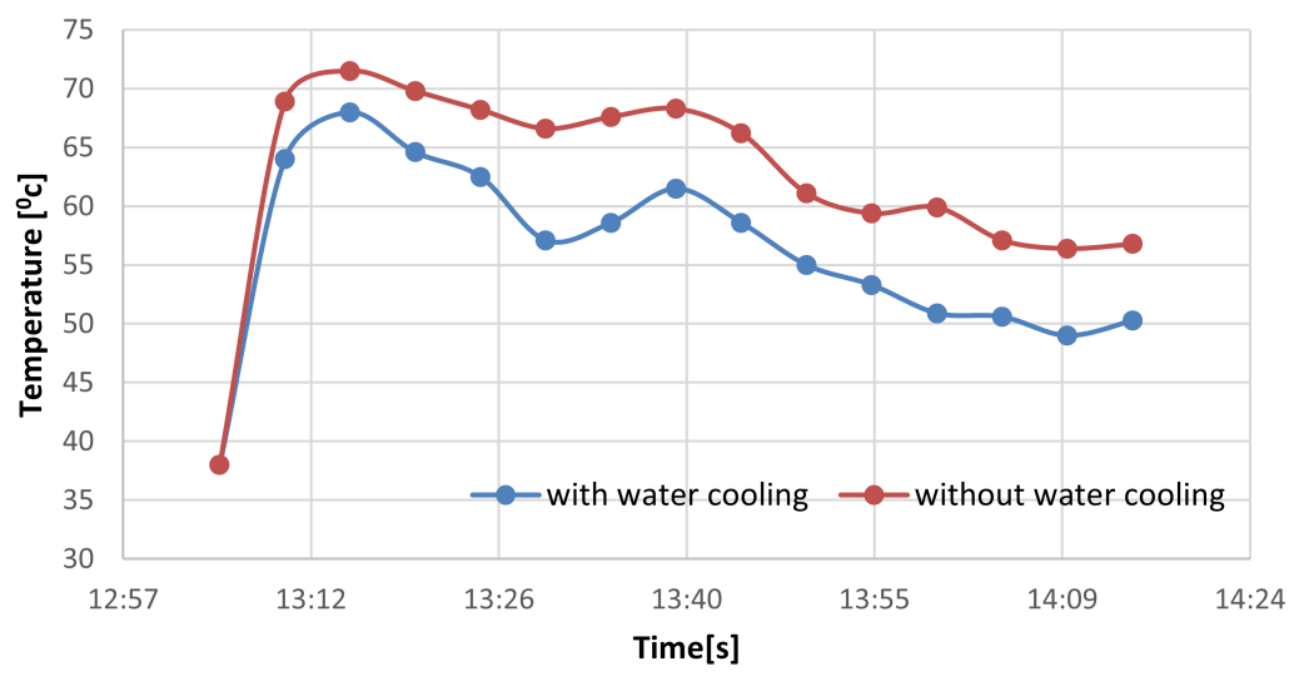

Figure 7: Experimental measurements of the module temperature versus time at the peak sun hours

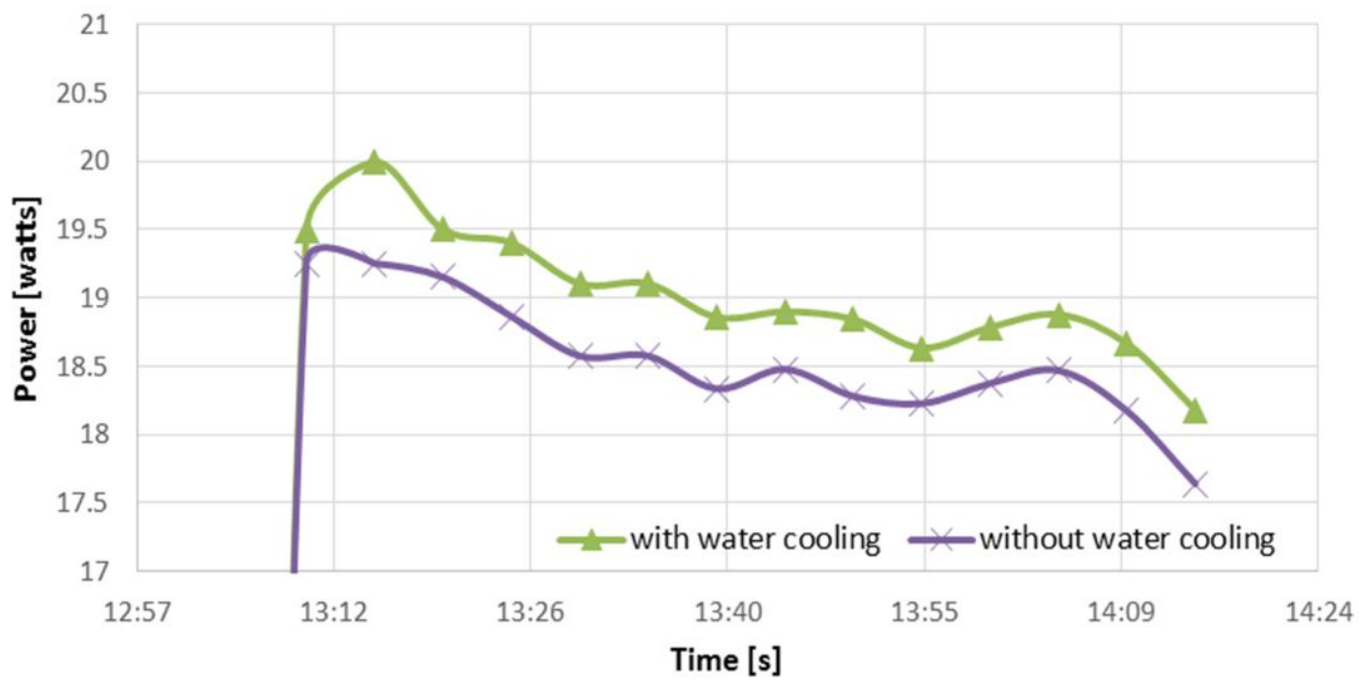

Figure 8: The modules' output power versus time at the peaks sun hours 


\subsection{Fins cooling technique results}

\section{Temperature changing with time}

This experiment, investigate the effect of fins cooling technique on panels' temperature. First panel was left without any cooling, while the other one was added by four similar fins to absorb heat. Panels' temperature and output power were measured at the peak sun hours. This cooling method reduced the temperature of the panel about $3{ }^{0} \mathrm{C}$ lower than the panel without cooling, as shown in (Figure 9).

\section{Power changing with time}

This figure represent the relation between the output power and time where power raised up nearly 0.5 watt i.e. $2.5 \%$ of total power of the panel, as shown in (Figure 10).

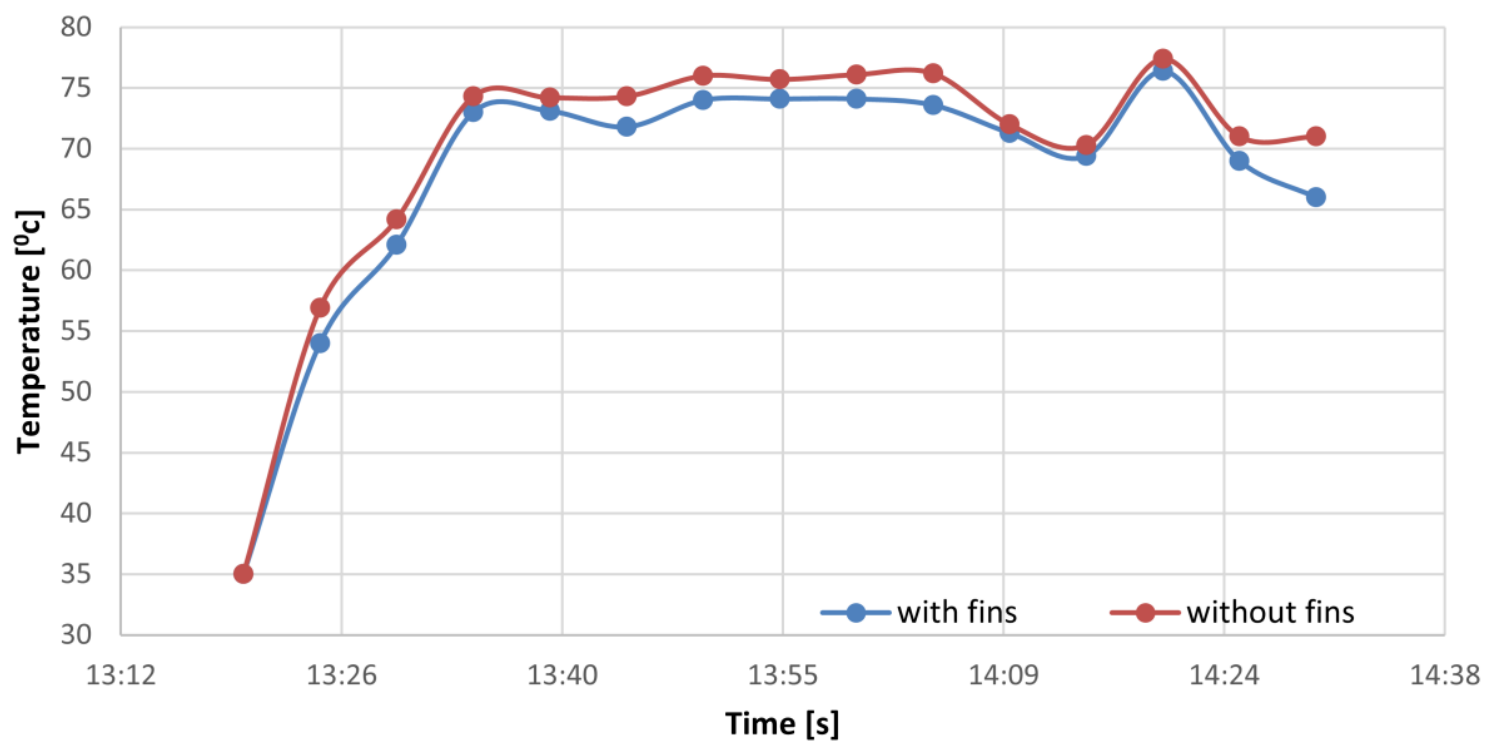

Figure 9: The effect of fins cooling technique on panels' temperature versus time at the peak sun hours

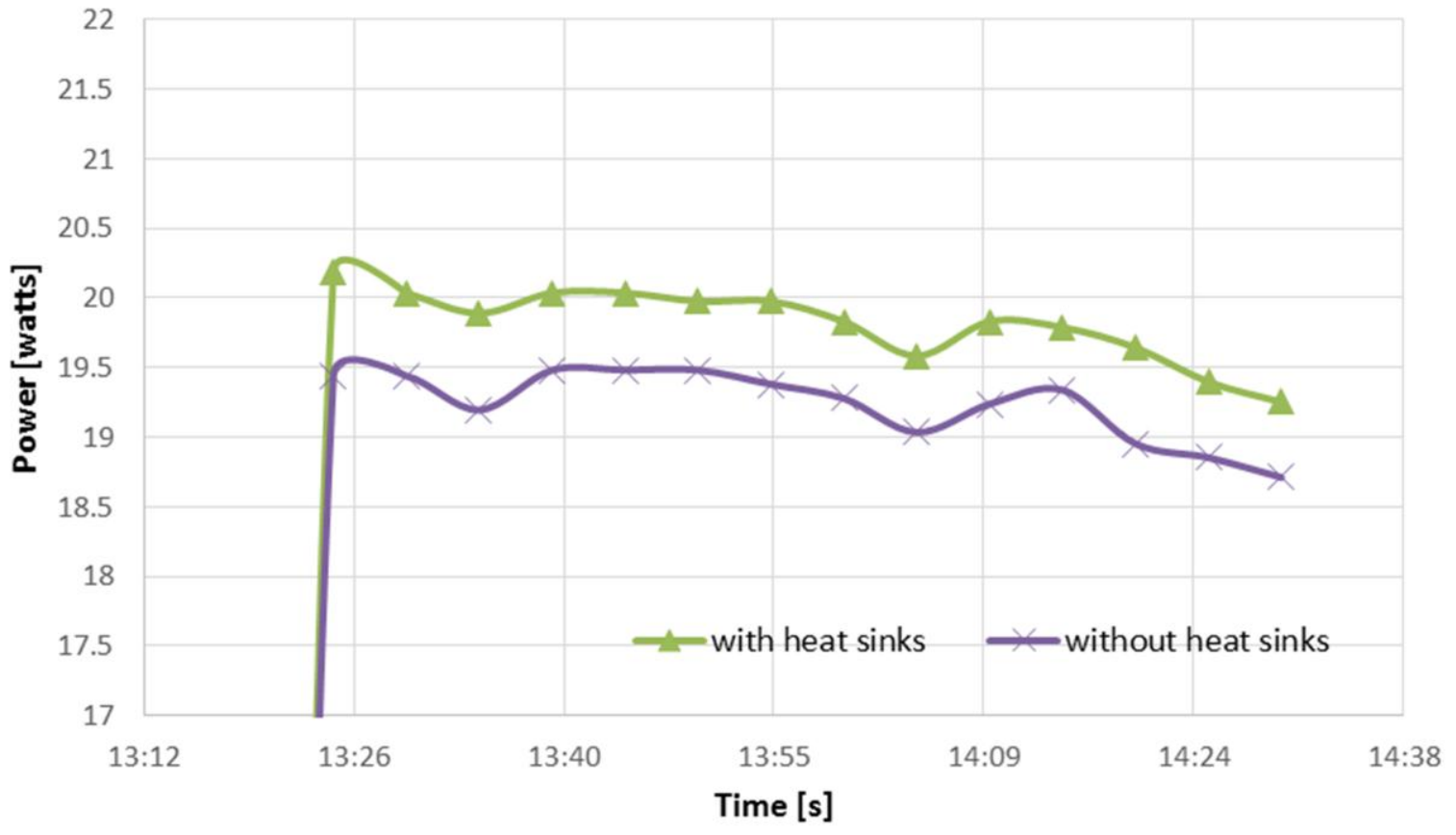

Figure 10: The output power versus time 


\subsection{Fins with fans cooling technique results}

\section{Temperature changing with time}

This experiment demonstrate the effect of fins with fans cooling technique first panel was left without any cooling, while the other one was added by four similar fins to absorb heat. Each fins module added with fan switched on every five minutes for 30 seconds to decrease the power consumed by fan.
The temperature and power were recorded at the peak sun hors. This cooling method reduced the temperature of the panel about $3{ }^{0} \mathrm{C}$ lower than the panel without cooling, as shown in (Figure 11).

\section{Power changing with time}

From the results, as the effect of cooling total output power of panels increased 0.5 watt as shown in (Figure 12).

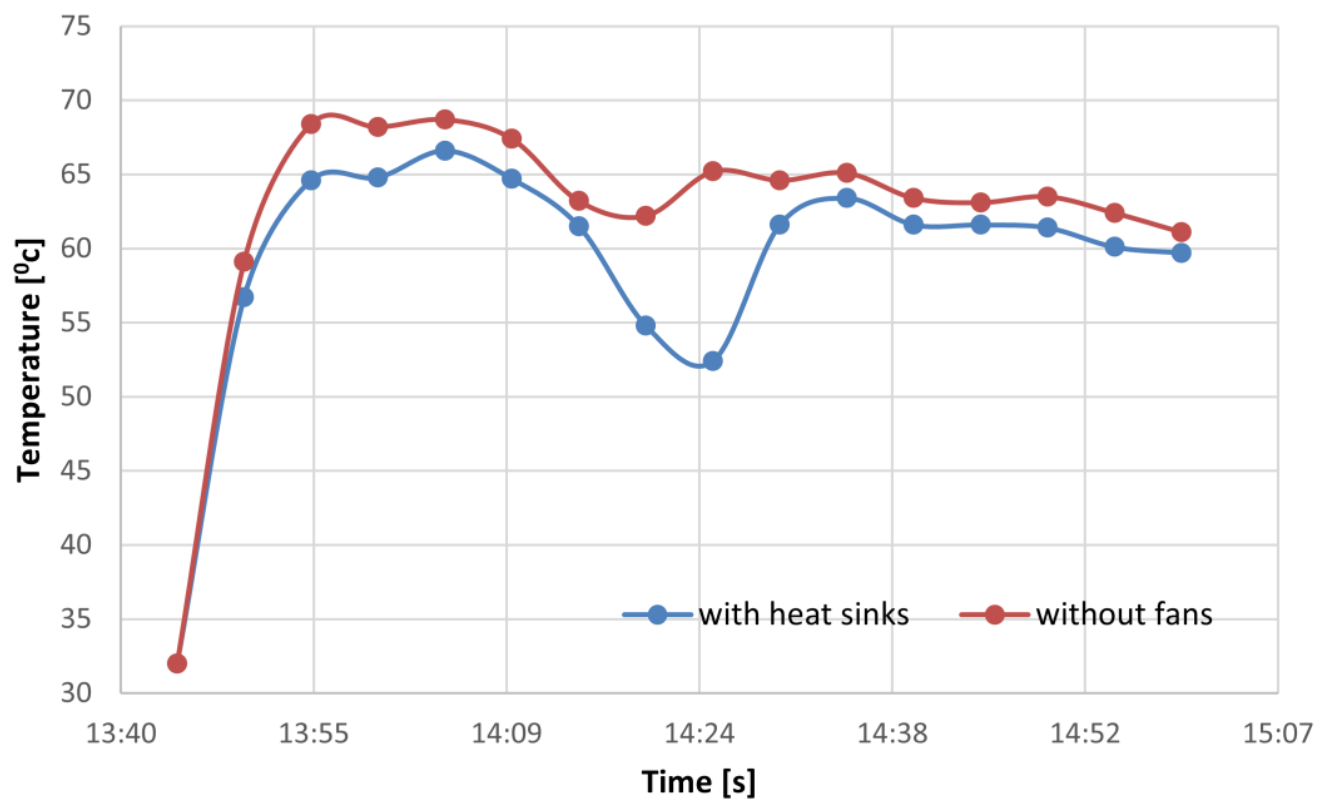

Figure 11: Effect of fins with fans on cell temperatureversus time

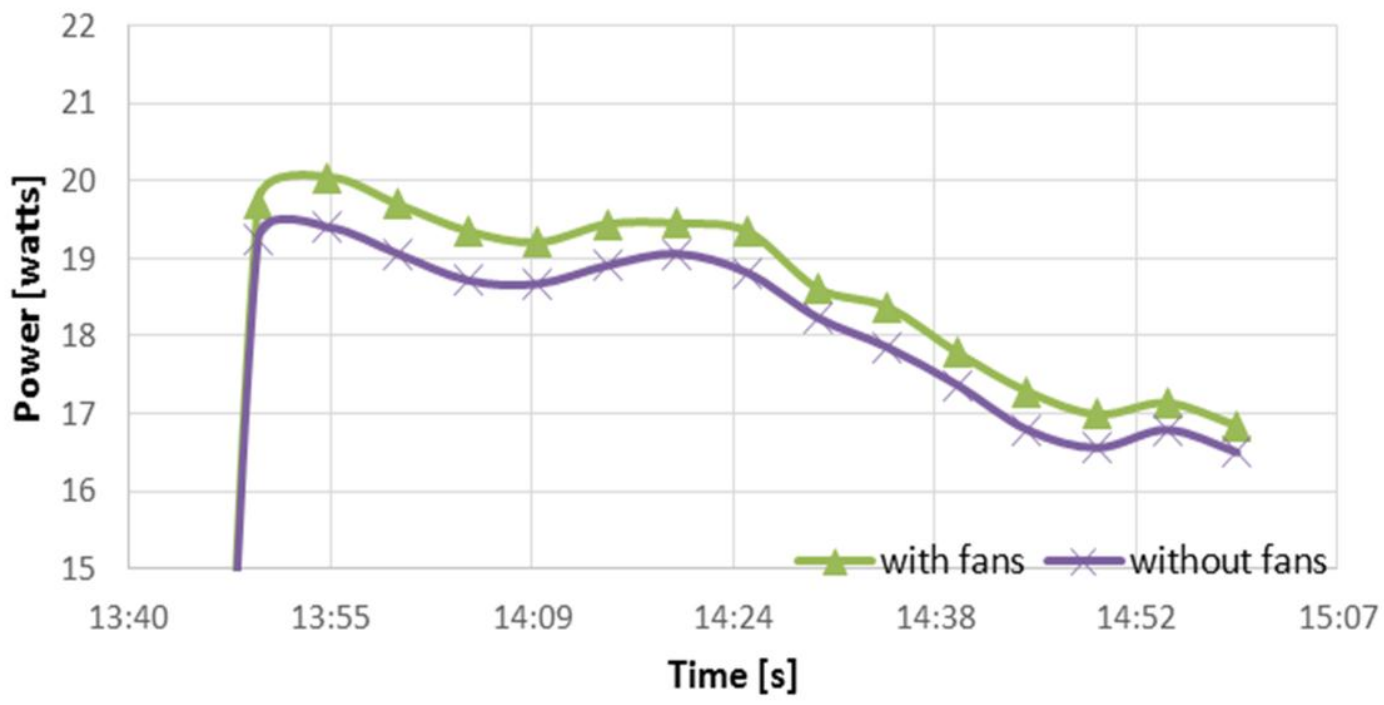

Figure 12: Effect of fins with fans on cell powerversus time 


\section{Power consumed statistics}

Fans voltage: $7.5 \mathrm{~V}$

Fans current: $0.4 \mathrm{~A}$

Fans power: 3 watts

Fans power/hours: $3 *(12 * 30) / 3600=0.3 \mathrm{watt} / \mathrm{H}$

Where, (12) represents is the numbers of pump switch on per hour, (30) represents time of switch off in seconds.

\section{Conclusion}

In this study, three cooling techniques were applied to study the influence of cooling on the performance of PV panels. The most effective technique give the best temperature drop was the water spray technique. The temperature dropped seven degrees during the peak sun hours that's mean it can obtain more drop in temperature in the lower temperature, The other cooling techniques give three degrees decrease in temperature. In all techniques, the power increased about $2.5 \%$ from the total power panel. The most effective technique was fins cooling due to its stability and as it does not need a power source compared with the other techniques which consumed power.

\section{References}

[1] J. Siecker, K. Kusakana, B.P. Numbi, "A review of solar photovoltaic systems cooling technologies", Renewable and Sustainable Energy Reviews 79 (2017) 192-203.

[2] Muzaffar Ali , Hafiz.M. Ali, Waqar Moazzam, and M. Babar Saeed: "Performance enhancement of PV cells through micro-channel cooling", AIMS Energy, 3(4): 699-710 (2015).

[3] Haitham M.S. Bahaidarah, Ahmer A.B. Baloch, Palanichamy Gandhidasan, "Uniform cooling of photovoltaic panels", Renewable and Sustainable Energy Reviews 57 (2016) 1520-1544.

[4] S. Nižtic', A.M. Papadopoulos, E. Giama, "Comprehensive analysis and general economic-environmental evaluation of cooling techniques for photovoltaic panels, Part I: Passive cooling techniques", Energy Conversion and Management 149 (2017) 334-354.

[5] S. Nižetic', A.M. Papadopoulos, E. Giama, "Comprehensive analysis and general economic-environmental evaluation of cooling techniques for photovoltaic panels, Part II: Active cooling techniques", Energy Conversion and Management 155 (2018) 301-323.

[6] S. Nižetic', D. C`oko, A. Yadav , F. Grubišic' -C`abo, "Water spray cooling technique applied on a photovoltaic panel: The Performance response", Energy Conversion and Management 108 (2016) 287-296.

[7] K.A. Moharram, M.S. Abd-Elhady, H.A. Kandil, H. El-Sherif, "Enhancing the performance of photovoltaic panels by water cooling", Ain Shams Engineering Journal (2013) 4, 869-877.

[8] Xiao Tang, Zhenhua Quan, Yaohua Zhao: "Experimental Investigation of Solar Panel Cooling by a Novel Micro Heat Pipe Array", Energy and Power Engineering, 2010, 2, 171-174.

[9] Saurabh Mehrotra, Pratish Rawat, Mary Debbarma and K. Sudhakar: "Performance Of A Solar Panel With Water Immersion Cooling Technique", International Journal of Science, Environment and Technology, Vol. 3, No 3, 2014, $1161-1172$.

[10] PWX 500 PV module data-sheet; January 2005. 